\title{
Costatone C-A New Halogenated Monoterpene from the New Zealand Red Alga Plocamium angustum
}

\author{
Joe Bracegirdle 1,2,3®D, Zaineb Sohail ${ }^{4}$, Michael J. Fairhurst ${ }^{2,5}$, Monica L. Gerth 2,3,5, \\ Giuseppe C. Zuccarello ${ }^{5}$, Muhammad Ali Hashmi ${ }^{6}(\mathbb{D})$ and Robert A. Keyzers ${ }^{1,2,3, *}$ \\ School of Chemical and Physical Sciences, Victoria University of Wellington, Wellington 6012, New Zealand \\ Centre for Biodiscovery, Victoria University of Wellington, Wellington 6012, New Zealand \\ Maurice Wilkins Centre for Molecular Biodiscovery, Wellington 6012, New Zealand \\ Department of Life Sciences, University of Management and Technology, C-II, \\ Johar Town Lahore 54770, Pakistan \\ 5 School of Biological Sciences, Victoria University of Wellington, Wellington 6012, New Zealand \\ 6 Department of Chemistry, University of Education, Attock Campus, Attock 43600, Pakistan \\ * Correspondence: robert.keyzers@vuw.ac.nz; Tel.: +64 44635117
}

Received: 21 June 2019; Accepted: 17 July 2019; Published: 19 July 2019

check for updates

\begin{abstract}
Red algae of the genus Plocamium have been a rich source of halogenated monoterpenes. Herein, a new cyclic monoterpene, costatone C (7), was isolated from the extract of P. angustum collected in New Zealand, along with the previously reported (1E,5Z)-1,6-dichloro-2-methylhepta-1,5-dien-3-ol (8). Elucidation of the planar structure of 7 was achieved through conventional NMR and (-)-HR-APCI-MS techniques, and the absolute configuration by comparison of experimental and DFT-calculated ECD spectra. The absolute configuration of 8 was determined using Mosher's method. Compound 7 showed mild antibacterial activity against Staphylococcus aureus and S. epidermidis. The state of Plocamium taxonomy and its implications upon natural product distributions, especially across samples from specimens collected in different countries, is also discussed.
\end{abstract}

Keywords: halogenated monoterpene; Plocamium angustum; costatone; Mosher's analysis; DFT; ECD

\section{Introduction}

Red algae, found in marine habitats around the world, generate a huge range of structurally diverse natural products. New Zealand is home to a large variety of red algal species, including the genus Plocamium. This genus has been a prolific source of halogenated monoterpenes, often showing antibacterial or cytotoxic bioactivity [1], and is therefore of interest for drug discovery.

P. angustum is found throughout the Pacific Islands and the length of New Zealand, and is also very common around Australia, the origin of the alga for all previous published chemical investigations. In 1979, Dunlop et al. reported the isolation of the novel bromodichloro monoterpene 1 alongside the previously reported dienone $\mathbf{2}$ from an alga collected from South Australia [2]. Two separate studies focusing on algae collected in Victoria, Australia, resulted in the isolation of three other highly halogenated monoterpenes (3-5) (Scheme 1), where plocamenone (4) showed both antibacterial and antifungal activity [3,4]. Thus far, there have been no reports of studies on P. angustum collected in New Zealand. 
<smiles>C=C(C)C(C)C/C=C(\C)C(Cl)CBr</smiles>

1<smiles>C=C(C)C(=O)/C(Cl)=C\[C@@](C)(Cl)[C@H](Br)CCl</smiles>

4<smiles>CC(=CCl)[C@@H]1C[C@@H](Br)[C@@](Cl)(CCl)[C@@H](CBr)O1</smiles>

7<smiles>C=C(C)C(=O)/C=C(\Cl)C(C)(Cl)C(Br)CCl</smiles>

2<smiles>C=C(C)C(=O)/C(Cl)=C/[C@@](C)(Cl)[C@H](Br)CCl</smiles>

5<smiles>[3H]/C(Cl)=C/C[C@H](O)/C([B])=C/Cl</smiles>

8<smiles>CC(=CCl)[C@@H]1CC(Cl)=C(C)[C@](O)(C(Br)Br)O1</smiles>
3<smiles>CC(=CCl)[C@@H]1CC(Cl)=C(C)[C@@H](CBr)O1</smiles>

6<smiles>[R1]C=C(C)C(Cl)CC([R2])[C@@]([R3])(C)C(O)C[R4]</smiles>

$9 \quad \mathrm{R}_{1}=\mathrm{Cl} \mathrm{R} \mathrm{R}_{2}=\mathrm{Br} \quad \mathrm{R}_{3}=\mathrm{Br} \quad \mathrm{R}_{4}=\mathrm{Cl}$

$10 \mathrm{R}_{1}=\mathrm{Cl} \mathrm{R} \mathrm{R}_{2}=\mathrm{Cl} \mathrm{R} \mathrm{R}_{3}=\mathrm{Br} \mathrm{R}_{4}=\mathrm{Br}$

$11 \mathrm{R}_{1}=\mathrm{Br} \mathrm{R}_{2}=\mathrm{Cl} \mathrm{R} \mathrm{R}_{3}=\mathrm{Cl} \mathrm{R} \mathrm{R}_{4}=\mathrm{Br}$

Scheme 1. Chemical structures of previously isolated halogenated monoterpenes from Plocamium spp.

Recent studies have shown that morphological species identification in algae is not accurate in determining species status, i.e. independent evolutionary lineages, suggesting that only with molecular data can morphologically similar but distinct species be determined [5]. Incorrect species identification could explain some of the differences in natural product content, if such contents are species specific. Plocamium is a genus to which molecular taxonomic methods have been applied, revealing that morphological identification, especially of the commonly named entity P. cartilagineum, does not conform to evolutionary lineages [6,7]. In New Zealand, six named species of Plocamium have been reported [8], while a recent study indicates that at least eleven species are found in New Zealand, and that there are no morphological characters to distinguish among these species [9].

Costatone A (3) [10] and B (6) [11] are cyclic polyhalogenated monoterpenes, first isolated from different $P$. costatum samples collected in South Australia. The absolute configuration of costatone A was solved by X-ray crystallography, and has since been isolated from samples identified as $P$. angustum [4]. As part of our investigation into the secondary metabolites of common Rhodophytes collected from the coast of Wellington, New Zealand [12], it was observed using ${ }^{1} \mathrm{H}$ NMR spectroscopy that an extract of an alga identified as "P. angustum" had many chemical shifts indicative of halogenated monoterpenes. A detailed analysis of the alga resulted in the isolation of the two major compounds that have not been previously reported from "P. angustum", new compound $\mathbf{7}$ and known compound 8 (Scheme 1). Costatone C (7) is the first polyhalogenated monoterpene with a tetrahydropyran ring isolated from this species.

\section{Results and Discussion}

The methanolic extract of $P$. angustum (50.0 g wet weight) was partitioned over polystyrene(divinylbenzene) using increasing percentages of acetone in $\mathrm{H}_{2} \mathrm{O}$. The ${ }^{1} \mathrm{H}$ NMR spectrum of the $75 \%$ acetone in $\mathrm{H}_{2} \mathrm{O}$ fraction showed many resonances attributable to halogenated monoterpenes, 
and was consequently purified by size-exclusion chromatography, yielding two major components by TLC. Reversed-phase HPLC was then used to purify the resulting compounds.

Compound 7 was isolated as a yellow oil. A molecular formula of $\mathrm{C}_{10} \mathrm{H}_{14} \mathrm{OCl}_{2} \mathrm{Br}_{2}$ was established from negative ion high resolution atmospheric-pressure chemical ionisation mass spectrometry ((-)-HR-APCI-MS) analysis. This molecular formula is indicative of a monoterpene, and requires two degrees of unsaturation, one accounted for by an alkene as evidenced by the two downfield ${ }^{13} \mathrm{C}$ resonances (in $\mathrm{CD}_{3} \mathrm{OD}$ as $\mathrm{CDCl}_{3}$ had overlapping resonances) $\delta_{\mathrm{C}} 138.5$ and 117.5 (Table 1). The ${ }^{13} \mathrm{C}$ NMR and multiplicity-edited HSQC spectra also showed signals for a non-protonated carbon $\left(\delta_{C} 73.6\right)$, three methines $\left(\delta_{C} 83.4,73.8,54.5\right)$, two methylenes $\left(\delta_{C} 39.1,29.0\right)$ and two methyl groups $\left(\delta_{C} 28.9\right.$, 13.1), with the olefinic carbon $\mathrm{C}-1\left(\delta_{\mathrm{C}} 117.5\right)$ also bearing one hydrogen $\left(\mathrm{H}-1 \delta_{\mathrm{H}} 6.28\right)$. The resonance for $\mathrm{H}-1$ appears as a quintet $(\mathrm{J}=1.4 \mathrm{~Hz})$ and shows a COSY correlation to the vinylic methyl, along with an allylic coupling to $\mathrm{H}-3\left(\delta_{\mathrm{H}} 4.22\right)$. Further COSY correlations from $\mathrm{H}-3$ assigned the remainder of the spin system, first to methylene $\mathrm{H}_{2}-4\left(\delta_{\mathrm{H}} 2.45,2.15\right)$ and methine $\mathrm{H}-5\left(\delta_{\mathrm{H}} 4.75\right)$. A second spin system deduced from COSY correlations connected the other oxygenated methine $\mathrm{H}-7\left(\delta_{\mathrm{H}} 4.29\right)$ to methylene $\mathrm{H}_{2}-8\left(\delta_{\mathrm{H}} 3.94,3.73\right)$. These two fragments are linked via non-protonated C-6 $\left(\delta_{\mathrm{C}} 73.6\right)$, based upon two- and three-bond $\mathrm{HMBC}$ correlations from $\mathrm{H}_{2}-4, \mathrm{H}-5, \mathrm{H}-7$ and $\mathrm{H}_{2}-8$. As the molecular formula requires another degree of unsaturation, and $\mathrm{H}-3$ correlates in the HMBC spectrum to C-7, the molecule must be cyclic, containing a tetrahydropyran moiety (Figure 1).

Table 1. NMR data for costatone $\mathrm{C}(7), \mathrm{CD}_{3} \mathrm{OD}$.

\begin{tabular}{ccccc}
\hline Position & $\delta_{\mathbf{C}^{\mathbf{a}}}$ & $\delta_{\mathbf{H}}{ }^{\mathbf{b}}$ & COSY & HMBC \\
\hline 1 & $117.5, \mathrm{CH}$ & $6.28($ quin, 1.4) & 3,9 & $2,3,9$ \\
2 & $138.5, \mathrm{C}$ & & & \\
3 & $73.8, \mathrm{CH}$ & $4.22(\mathrm{dd}, 11.7,2.6)$ & $1,4,9$ & $1,2,4,5,7,9$ \\
4 & $39.1, \mathrm{CH}_{2}$ & $2.45(\mathrm{dt}, 12.9,11.9)$ & $3,4,5$ & $2,3,5$ \\
& & $2.15(\mathrm{ddd}, 12.9,4.4$, & $3,4,5$ & 3,5 \\
5 & $54.5, \mathrm{CH}$ & $4.75(\mathrm{dd}, 12.0,4.4)$ & 4 & $3,4,6,10$ \\
6 & $73.6, \mathrm{C}$ & & & \\
7 & $83.4, \mathrm{CH}$ & $4.29(\mathrm{dd}, 11.7,3.9)$ & 8 & $3,5,6,8,10$ \\
8 & $29.0, \mathrm{CH}_{2}$ & $3.94(\mathrm{t}, 11.6)$ & 7,8 & 6,7 \\
9 & $13.1, \mathrm{CH}_{3}$ & $1.73(\mathrm{dd}, 11.6,3.9)$ & 7,8 & $7 \mathrm{~d}, 1.4)$ \\
10 & $28.9, \mathrm{CH}_{3}$ & $1.70(\mathrm{~s})$ & 1,3 & $1,2,3$ \\
\hline
\end{tabular}

a $150 \mathrm{MHz} ;{ }^{\text {b }} 600 \mathrm{MHz}$, (multiplicity, $\left.J(\mathrm{~Hz})\right)$.

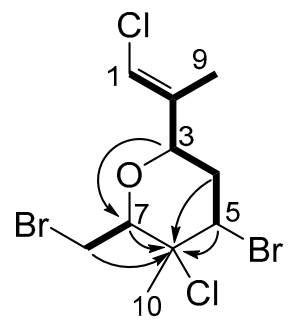

Figure 1. Key HMBC and COSY correlations used to establish the planar structure of costatone C (7).

The ${ }^{13} \mathrm{C}$ NMR signal for C- 6 at $\delta_{\mathrm{C}} 73.6$ was split into an asymmetric doublet, with an intensity ratio of $\sim 3: 1$, a phenomenon known as the chlorine isotope effect [13], thus there must be a chlorine present at this centre. The locations of the remaining halogens were then assigned on the basis of chemical shift arguments. Motti et al. isolated costatols C-E (9-11) from P. costatum, (Scheme 1), where each also have an $E$ trisubstituted double bond, however $\mathbf{9}$ and $\mathbf{1 0}$ are chlorinated while $\mathbf{1 1}$ is brominated at position C-1 [11]. Clearly, the ${ }^{13} \mathrm{C}$ NMR data of C-1 and C-2 for 7 ( $\delta_{C} 117.5$ and 138.5) align with a chlorovinyl 
group $\left(9 \delta_{\mathrm{C}} 116.1\right.$ and $138.8,10 \delta_{\mathrm{C}} 116.2$ and $138.7,11 \delta_{\mathrm{C}} 105.6$ and 141.7$)$, thus the other chlorine was assigned at $\mathrm{C}-1$. As no other ${ }^{13} \mathrm{C}$ signals were split, assigning the chlorine atom to a sp ${ }^{2}$ carbon is in agreement with the note that the splitting decreases with increased $s$ character of the carbon atom [13]. This necessitates bromine substituents to be at $C-5$ and $C-8$, which was further evidenced by their more shielded ${ }^{13} C$ shifts $\left(\delta_{C} 54.5\right.$ and 29.0 , respectively).

With the planar structure of $\mathbf{7}$ in hand, the geometry of the alkene and relative configuration of the four chiral centres were deduced from through space 2D ROESY NMR correlations and ${ }^{1} \mathrm{H} N M R$ coupling constants. The double bond must have an $E$ geometry on the basis of the through-space ROESY correlation between $\mathrm{H}-1$ and $\mathrm{H}-3$, with ${ }^{13} \mathrm{C}$ NMR data consistent with that of co-isolated compound 8 that also possess a similar E-chloroalkene [14,15]. H-3 and H-5 both show ROESY correlations to the same proton $\mathrm{H}-4_{\mathrm{b}}(2.15 \mathrm{ppm})$, with smaller coupling constants $\left(J_{\mathrm{H}-3 / \mathrm{H}-4 b}=2.6 \mathrm{~Hz}, J_{\mathrm{H}-4 b / \mathrm{H}-5}=4.4\right.$ $\mathrm{Hz}$ ) indicative of axial/equatorial relationships, whereas no ROESY correlations were observed to $\mathrm{H}-4_{\mathrm{a}}$, but large coupling constants suggest axial/axial couplings $\left(\mathrm{J}_{\mathrm{H}-3 / \mathrm{H}-4 a}=11.7 \mathrm{~Hz}, \mathrm{~J}_{\mathrm{H}-4 a / \mathrm{H}-5}=12.0\right.$ $\mathrm{Hz}$ ), therefore $\mathrm{H}-3$ and $\mathrm{H}-5$ are syn, corroborated by their shared nOe correlation. The through-space ROESY correlations among $\mathrm{H}-5, \mathrm{H}-\mathrm{B}_{\mathrm{a}}$ and methyl $\mathrm{H}_{3}-10$ put these substituents on the same side of the ring as well, further evidenced by $\mathrm{H}-8 \mathrm{a}$ 's correlation to $\mathrm{H}-3$. Thus, the relative configuration $3 R$, $5 R, 6 S, 7 R$ was deduced as depicted (Scheme 1). This favoured conformation minimises 1,3-diaxial interactions of the chair by orientating most of the bulky groups in equatorial positions, consistent with the observed scalar ${ }^{1} \mathrm{H}$ coupling constants.

Where crystallographic data are unobtainable, computational chemistry can play a significant role in establishing the absolute configuration of a compound if experimental electronic circular dichroism (ECD) data are available. Computation of ECD data and their comparison to experimental data can lead to the assignment of absolute configuration. For this purpose, the structure of 7 (Figure 2) was optimised at the PBE0-D3BJ/aug-cc-pVTZ/SMD $\mathrm{MeOH}_{\mathrm{H}}$ level of theory followed by a relaxed scan by varying two key dihedrals (C4-C3-C2-C9 and C6-C7-C8-Br) in 24 steps of $15^{\circ}$ each. After that, the lowest energy conformations were selected from the resulting potential energy surface (PES) as shown (Figure S24). After removal of duplicates, ten conformers were subjected to ECD computations using time-dependent density functional theory (TDDFT) and the results were compared with the experimental $\mathrm{CD}$ spectrum obtained in $\mathrm{MeOH}$ after summing based upon their Boltzmann weightings (Figure 3). The computed ECD spectrum was scaled for its peak intensity and wavelength to match with the experimental spectrum [16-18]. The computed ECD spectrum is in a very good agreement to the experimental, which confirms the absolute configuration of compound 7 as $3 R, 5 R, 6 S, 7 R$, as shown in Figure 3.

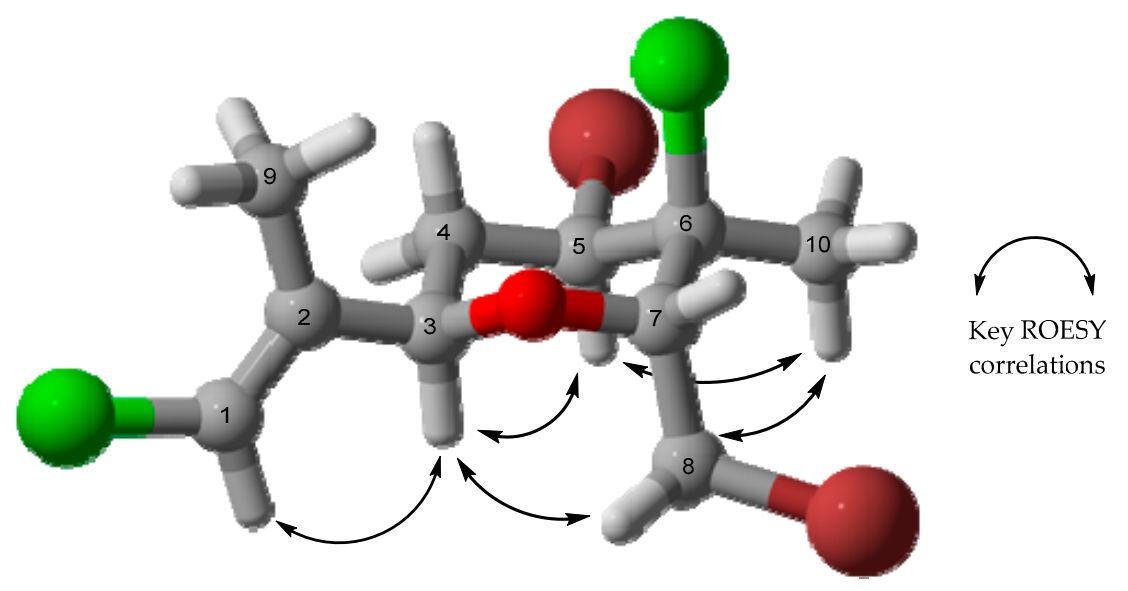

Figure 2. Optimised geometry of the lowest energy conformer of 7 at PBE0-D3BJ/aug-cc-pVTZ/ $\mathrm{SMD}_{\mathrm{MeOH}}$ level of theory. Key experimental ROESY correlations are shown by arrows. 


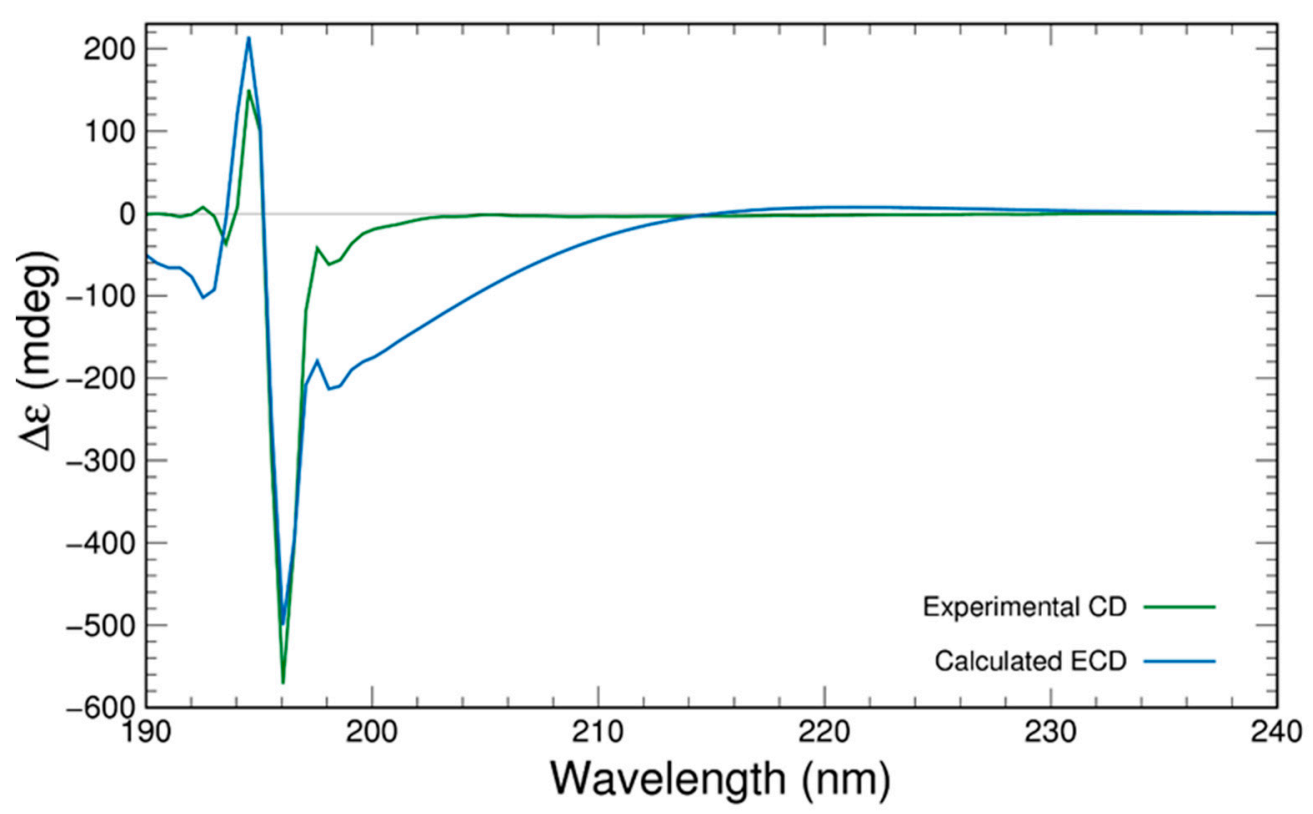

Figure 3. Experimental CD spectrum of 7 in $\mathrm{MeOH}$ compared with the Boltzmann averaged spectrum computed at the PBE0-D3BJ/aug-cc-pVTZ/SMD $\mathrm{MeOH}_{\mathrm{H}}$ level of theory.

The dichlorinated bisnor-monoterpene (1E,5Z)-1,6-dichloro-2-methylhepta-1,5-dien-3-ol (8) was also isolated as the major metabolite. Terpene $\mathbf{8}$ was initially reported from P. cruciferum and was identified here by comparison to the reported NMR and EI-MS data $[14,15]$. The absolute configuration at C-3 was not determined originally, therefore Mosher's ester analysis was used to derivatise the secondary alcohol [19]. Both R- and S-MTPA esters were produced under Steglich conditions [20], with subsequent NMR analysis leading to the conclusion that $\mathrm{C}-3$ has an $S$ configuration (Figure 4). As the observed optical rotation (-22) agrees with that previously reported (-9.8), this established the absolute stereostructure of the P. cruciferum metabolite [14,15].

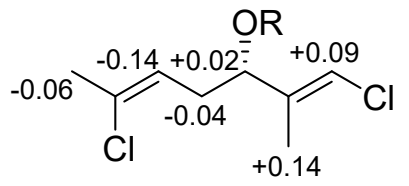

12a : R=(S)-MTPA

12b : R=(R)-MTPA

Figure 4. $\Delta \delta_{S-R}$ values in ppm of the MTPA esters of 8 .

The antibacterial properties of $\mathbf{7}$ and $\mathbf{8}$ were assessed using Pseudomonas aeruginosa (Gram negative), Staphylococcus aureus (Gram positive) and Staphylococcus epidermidis (Gram positive) (Figure S21). Although no inhibitory activity was detected against $P$. aeruginosa, 7 showed mild activity against both S. aureus and S. epidermidis, with minimum inhibitory concentrations (MIC) of 128 and $64 \mu \mathrm{M}$, respectively. No antibacterial activity was observed for $\mathbf{8}$.

Although morphologically identified as P. angustum, phylogenetic analysis with the cytochrome oxidase subunit 1 gene (Figure 5) and the ribulose bisphosphate carboxylase large subunit (data not shown) confirmed that this alga is a cryptic species $G$ [9]. Comparison with other available sequences indicates that this species is found in the Wellington region and along the Wairarapa coast (southeast North Island). This alga is distinct both from other New Zealand species and from Australian species identified as P. angustum (Figure S22) [9]. The sample is most similar to sequences identified as P. cartilagineum from New Zealand, however P. cartilagineum is a European species and therefore is unlikely to be a correct identification. This indicates that additional interesting chemistries could be discovered within the many cryptic species of Plocamium found in New Zealand and around the world. 


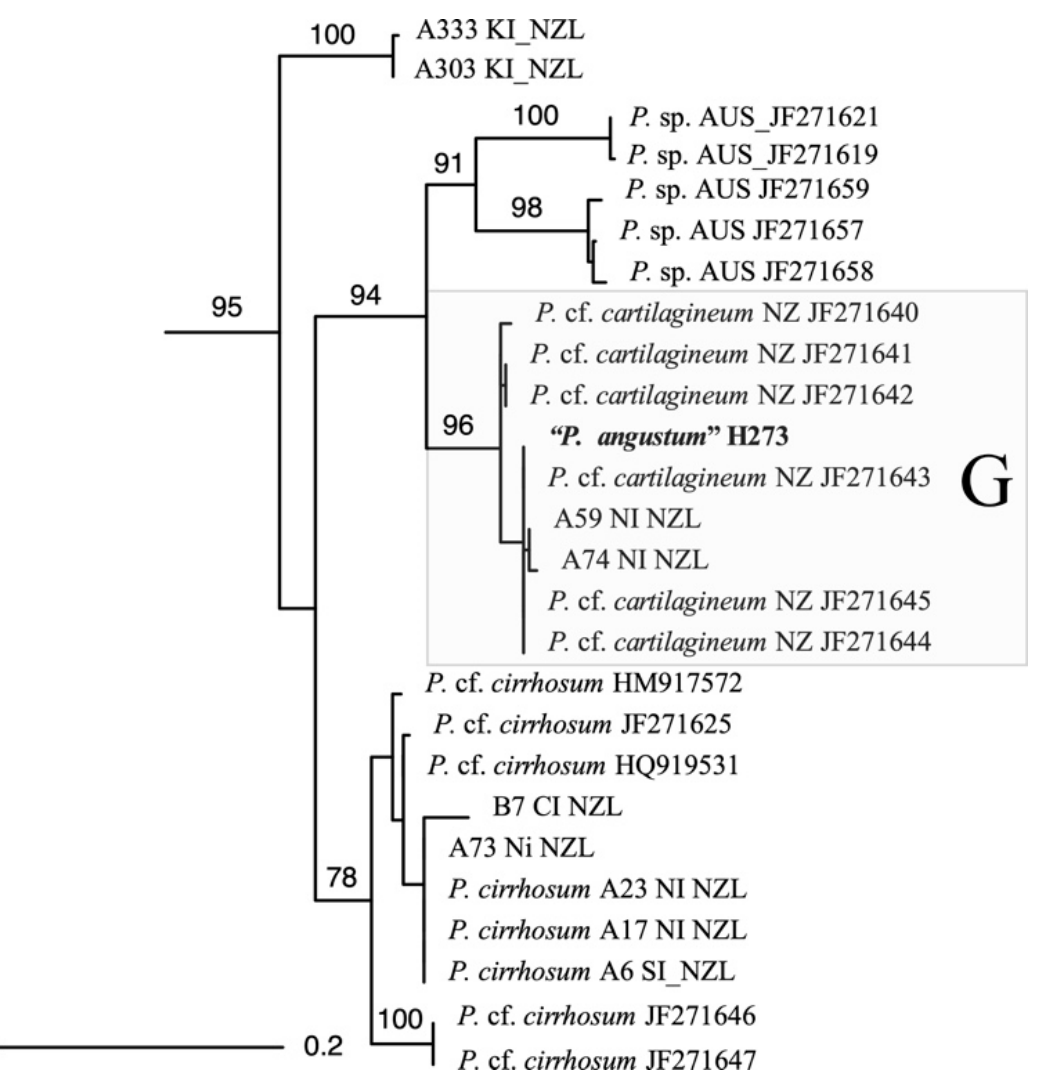

Figure 5. Phylogenetic analysis (maximum-likelihood) of various Plocamium species related to the species under investigation ("P. angustum" H273) (full dataset in Figures S1-S14).

\section{Conclusions}

Red algae of the genus Plocamium continue today to be a rich source of new halogenated monoterpenes. Through chromatographic techniques, the dibromo-dichloro-tetrahydropyran costatone C 7 was purified, and its structure and relative configuration solved by MS and NMR. By comparison of its theoretical and experimental ECD spectra, the absolute configuration was solved. As our study focused on an alga collected in New Zealand, there is clearly a different chemotype relative to those previously reported from Australia, and this is possibly due to the different species status of these morphologically similar algae, warranting further investigation into the metabolomics and taxonomy of these species.

\section{Materials and Methods}

\subsection{General Procedures}

Optical rotations were measured using a Rudolph Autopol II polarimeter. ECD spectra were recorded on a ChiraScan CD spectrometer (Applied Photophysics, Surrey, United Kingdom). A $600 \mathrm{MHz}$ Varian Direct Drive spectrometer equipped with a $5 \mathrm{~mm}$ PFG dual broadband probe was used to record the NMR spectra of 7, 8 and $8 \mathbf{a}, \mathbf{b}\left(600 \mathrm{MHz}\right.$ for ${ }^{1} \mathrm{H}$ nuclei and $150 \mathrm{MHz}$ for ${ }^{13} \mathrm{C}$ nuclei). The residual solvent peak was used as an internal reference for ${ }^{1} \mathrm{H}\left(\delta_{\mathrm{H}} 3.31, \mathrm{CD}_{3} \mathrm{OD} ; 7.26, \mathrm{CDCl}_{3}\right)$ and ${ }^{13} \mathrm{C}$ $\left(\delta_{\mathrm{C}} 49.0, \mathrm{CD}_{3} \mathrm{OD} ; 7.16, \mathrm{CDCl}_{3}\right)$ chemical shifts [21]. High-resolution (APCI) mass spectrometric data were obtained with an Agilent 6530 Accurate Mass Q-TOF LC-MS (Santa Clara, CA, USA) equipped with a 1260 Infinity binary pump. IR (film) spectra were recorded using a Bruker Platinum Alpha FTIR spectrometer (Leipzig, Germany). EI mass spectrometric data were acquired using a Shimadzu 2010 Plus gas chromatograph (Kyoto, Japan) operating with a GCMS-QP2010 MS detector. 
Reversed-phase column chromatography was achieved using Supelco Diaion HP20 (PSDVB) chromatographic resin. Size exclusion chromatography was achieved using Sephadex LH20 resin. HPLC purifications were carried out using either an Agilent Technologies 1260 Infinity HPLC equipped with a diode array detector or an Agilent 380 evaporative light-scattering detector (ELSD), using an octadecyl-derivatised silica $\left(C_{18}, 5 \mu \mathrm{m}, 100 \AA\right.$ ) HPLC column (Phenomenex; $4.6 \mathrm{~mm} \times 250 \mathrm{~mm}$, flow rate: $1 \mathrm{~mL} / \mathrm{min}$ ). All solvents used for column chromatography were of HPLC grade and $\mathrm{H}_{2} \mathrm{O}$ was glass distilled. Solvent mixtures are reported as per cent v/v unless otherwise stated. TLC was carried out using Machery-Nagel Polygram Sil G/UV 254 plates, run in 1:3 EtOAc:hexanes and developed using a $\mathrm{H}_{2} \mathrm{SO}_{4}(5 \%$ in $\mathrm{MeOH}) /$ vanillin $(0.1 \% \mathrm{w} / \mathrm{v}$ in $\mathrm{EtOH})$ char.

\subsection{Collection of Plocamium angustum}

Specimens of Plocamium angustum were collected by hand using scuba at a depth of 3-10 m from Moa Point, Wellington, New Zealand, in January 2017 and stored at $-20^{\circ} \mathrm{C}$ until extraction. A voucher specimen (JB06_38) is held at the School of Chemical and Physical Sciences, Victoria University of Wellington, New Zealand.

\subsection{Extraction and Isolation}

Frozen P. angustum (50.0 g wet weight) was extracted in $\mathrm{MeOH}(200 \mathrm{~mL})$ twice overnight. The second extract, followed by the first, were passed through a HP20 column $(30 \mathrm{~mL})$, pre-equilibrated in $\mathrm{H}_{2} \mathrm{O}$ and combined following elution. The eluent was then diluted with an equal volume of water and passed back through the column twice, followed by a $100 \mathrm{~mL} \mathrm{H}_{2} \mathrm{O}$ wash. The column was then eluted with $100 \mathrm{~mL}$ portions of: (1) $30 \% \mathrm{Me}_{2} \mathrm{CO} / \mathrm{H}_{2} \mathrm{O}$; (2) $75 \% \mathrm{Me}_{2} \mathrm{CO} / \mathrm{H}_{2} \mathrm{O}$; and (3) $\mathrm{Me}_{2} \mathrm{CO}$ (fractions A1-A3, respectively). Fraction A2 (300 mg) was then partitioned on Sephadex LH20 with $100 \% \mathrm{MeOH}$, and the resulting fractions were pooled together on the basis of TLC, resulting in two major fractions B1 (test tubes 36-43) and B2 (test tubes 44-51). A portion of sample B1 (20 mg) was subjected to silica gel chromatography (5:1 EtOAc:hexanes) to afford $8(6.8 \mathrm{mg})$ as a pale yellow oil. A portion of sample B2 $(10 \mathrm{mg})$ was further purified on a semipreparative C18 HPLC column $\left(80 \% \mathrm{MeOH} / \mathrm{H}_{2} \mathrm{O}\right)$, yielding compound $7\left(4.8 \mathrm{mg}, \mathrm{t}_{\mathrm{R}}=13.0 \mathrm{~min}\right)$ as a colourless oil.

Costatone $C$ (7): pale yellow oil, $[\alpha]_{\mathrm{D}}^{20}-7.2$ (c 0.05, $\left.\mathrm{CHCl}_{3}\right)$; IR $v$ (thin film): 2930, 1642, 1434, 1382, 1102, 1080, 782, 738, 587, $519 \mathrm{~cm}^{-1} ;{ }^{1} \mathrm{H}$ and ${ }^{13} \mathrm{C}$ NMR data, see Table $1 ;$ (-)HR-APCI-MS m/z 376.8719 $[\mathrm{M}-\mathrm{H}]^{-}$(calcd. for $\mathrm{C}_{10} \mathrm{H}_{13} \mathrm{OCl}_{2} \mathrm{Br}_{2}, 376.8716$ ).

Compound 8: colourless oil, $[\alpha]_{\mathrm{D}}^{20}-22\left(\right.$ c $\left.0.1, \mathrm{CHCl}_{3}\right)$; NMR and MS data consistent with published $[14,15]$.

\subsection{Preparation of MTPA esters $12 a$ and $12 b$}

A solution of EDC.HCl (12 mg, $64 \mu \mathrm{mol}), S-(+)-\alpha$-methoxyphenylacetic acid (15 mg, $64 \mu \mathrm{mol})$, and DMAP $(14.8 \mathrm{mg}, 120 \mu \mathrm{mol})$ was stirred in dry $\mathrm{CH}_{2} \mathrm{Cl}_{2}(0.5 \mathrm{~mL})$ under $\mathrm{Ar}$ at $0{ }^{\circ} \mathrm{C}$ for $10 \mathrm{~min}$ after which 8 ( $4 \mathrm{mg}, 12 \mu \mathrm{mol})$ in $\mathrm{CH}_{2} \mathrm{Cl}_{2}(0.5 \mathrm{~mL})$ was added. The solution was allowed to come to room temperature and stirred under $\mathrm{Ar}$ for $48 \mathrm{~h} . \mathrm{CH}_{2} \mathrm{Cl}_{2}(10 \mathrm{~mL})$ was added and the mixture was washed in turn with $10 \% \mathrm{HCl}(10 \mathrm{~mL}), \mathrm{H}_{2} \mathrm{O}(10 \mathrm{~mL})$, sat. $\mathrm{NaHCO}_{3}(10 \mathrm{~mL})$ and $\mathrm{H}_{2} \mathrm{O}(10 \mathrm{~mL})$ before being dried under reduced pressure. The sample was purified by flash silica gel chromatography (10:1 hexanes:EtOAc) to yield the crude product 12a, analysed without further purification. The procedure was repeated with $R-(-)-\alpha$-methoxyphenylacetic acid to yield product 12b (see Figure S17-S20 in the Supplementary Materials).

Compound 12a: ${ }^{1} \mathrm{H}$ NMR $\left(\mathrm{CDCl}_{3}, 600 \mathrm{MHz}\right) \delta_{\mathrm{H}} 7.48-7.40(5 \mathrm{H}, \mathrm{m}$, aromatics); $6.25(1 \mathrm{H}, \mathrm{s}, \mathrm{H}-1) ; 5.50$ (1H, dd, H-3); 5.18 (1H, t, H-5); 3.51 (3H, s, OMe); 2.56 (2H, m, H-4); 2.03 (3H, s, H-7); 1.75 (3H, d, H-8).

Compound 12b: ${ }^{1} \mathrm{H}$ NMR $\left(\mathrm{CDCl}_{3}, 600 \mathrm{MHz}\right) \delta_{\mathrm{H}} 7.48-7.40(5 \mathrm{H}, \mathrm{m}$, aromatics $) ; 6.16(1 \mathrm{H}, \mathrm{s}, \mathrm{H}-1) ; 5.48$ (1H, dd, H-3); 5.32 (1H, t, H-5); 3.55 (3H, s, OMe); 2.60 (2H, m, H-4); 2.09 (3H, s, H-7); 1.64 (3H, s, H-8). 


\subsection{Computational Data}

All computations were performed using Gaussian 09 (Revision D.01) [22]. Density functional theory (DFT) was used for all the calculations utilising Adamo's hybrid [23] version of Perdew, Burke and Ernzerhof functional (PBE0) $[24,25]$ along with the application of Grimme's empirical dispersion correction (D3) with Becke-Johnston damping (D3BJ) [26-28]. All calculations were performed with Ahlrich's triplet $\zeta$ basis set def2-TZVP [29] supported by the Polarisable Continuum Model (PCM) with the integral equation formalism variant (IEFPCM) [30-36] for solvation modelling. The solvent for optimisation and ECD calculation was $\mathrm{MeOH}$ which was modelled with the SMD parameter set by Cramer and Truhlar [37] (as implemented in Gaussian 09) [22]. Calculated ECD spectra were scaled for both intensity and frequency to the experimental data (Figure S23). Frequency calculations at the same level of theory were used to confirm all the optimised structures to be true minima on the potential energy surface with the absence of imaginary frequencies. The 3D images of optimised molecules were drawn using CYLview [38] program.

\subsection{Antibacterial Bioassay}

Pseudomonas aeruginosa (PAO1) or Staphylococcus aureus (ATCC 25923) were used to inoculate $100 \mu \mathrm{L}$ of Mueller Hinton broth (Formedium; Hunstanton, UK) amended with $100 \mu \mathrm{g} / \mathrm{mL}$ of the test compounds in a 96-well plate (control wells contained an equivalent volume of DMSO). Cells were incubated at $37^{\circ} \mathrm{C}$, shaking at $600 \mathrm{RPM}$, for $24 \mathrm{~h}$ (Incumix, Select Bioproducts; Edison, NJ, USA). The optical density was measured at $600 \mathrm{~nm}$ (Enspire 2300 Multilabel Reader, Perkin Elmer; Waltham, MA, USA) and the absorbance value of the media-only controls were averaged and subtracted from all measurements. Values were calculated from three replicates.

S. aureus and S. epidermidis (ATCC 35984) were then tested with 7 to determine the strength of inhibition in Gram-positive bacteria. Similar to the previous experiment, S. aureus and S. epidermidis were used to inoculate $100 \mu \mathrm{L}$ of Mueller Hinton broth, amended with a 2-fold dilution series of 7 from $0.5 \mu \mathrm{g} / \mathrm{mL}$ to $128 \mu \mathrm{g} / \mathrm{mL}$ in a 96-well plate (control wells contained an equivalent volume of DMSO). Cells were incubated at $37^{\circ} \mathrm{C}$, shaking at $600 \mathrm{RPM}$, for $24 \mathrm{~h}$. The optical density was measured at $600 \mathrm{~nm}$ and the absorbance value of the media-only controls were averaged and subtracted from all measurements. Values were calculated from three replicates.

\subsection{Molecular Analysis}

DNA extraction, PCR amplification, and sequencing of the cytochrome oxidase genes followed previously described method [9]. Various sequences of Plocamium were downloaded from Genbank or were gained directly from [9]. Phylogenetic trees were made using RAxML 8 [39] to construct maximum-likelihood trees (ML) to show the most likely tree from the dataset. RAxML was performed using the GTR+gamma model. The reliability of the ML topologies was evaluated based on 1000 nonparametric bootstrap replicates [40].

Supplementary Materials: The following are available online at http://www.mdpi.com/1660-3397/17/7/418/s1, Table S1: NMR data $\left(600 \mathrm{MHz}\right.$ for ${ }^{1} \mathrm{H}, 150 \mathrm{MHz}$ for $\left.{ }^{13} \mathrm{C}_{,} \mathrm{CD}_{3} \mathrm{OD}\right)$ of 7 , Figure $\mathrm{S1}:{ }^{1} \mathrm{H}$ Spectrum $\left(600 \mathrm{MHz}, \mathrm{CD}_{3} \mathrm{OD}\right)$ of 7, Figure S2: ${ }^{13} \mathrm{C}$ Spectrum ( $150 \mathrm{MHz}, \mathrm{CD}_{3} \mathrm{OD}$ ) of 7, Figure S3: COSY Spectrum $\left(600 \mathrm{MHz}, \mathrm{CD}_{3} \mathrm{OD}\right)$ of 7, Figure S4: HSQC Spectrum (600 MHz, $\left.\mathrm{CD}_{3} \mathrm{OD}\right)$ of 7, Figure S5: HMBC Spectrum (600 MHz, $\mathrm{CD}_{3} \mathrm{OD}$ ) of 7, Figure S6: ROESY Spectrum $\left(600 \mathrm{MHz}, \mathrm{CD}_{3} \mathrm{OD}\right)$ of 7 , Table S2: NMR data $\left(600 \mathrm{MHz}\right.$ for ${ }^{1} \mathrm{H}, 150 \mathrm{MHz}$ for $\left.{ }^{13} \mathrm{C}_{,} \mathrm{CDCl}_{3}\right)$ of 7, Figure S7: ${ }^{1} \mathrm{H}$ Spectrum $\left(600 \mathrm{MHz}, \mathrm{CDCl}_{3}\right)$ of 7, Figure $\mathrm{S8}:{ }^{13} \mathrm{C}$ Spectrum $\left(150 \mathrm{MHz}, \mathrm{CDCl}_{3}\right)$ of 7 , Figure S9: COSY Spectrum $\left(600 \mathrm{MHz}, \mathrm{CDCl}_{3}\right.$ ) of 7, Figure S10: HSQC Spectrum $\left(600 \mathrm{MHz}, \mathrm{CDCl}_{3}\right)$ of 7 , Figure S11: HMBC Spectrum $\left(600 \mathrm{MHz}, \mathrm{CDCl}_{3}\right)$ of 7, Figure S12: NOESY Spectrum (600 MHz, $\mathrm{CDCl}_{3}$ ) of 7, Figure S13: (-)HR-APCI-MS Spectrum of 7, Figure S14: IR Spectrum (film) of 7, Figure S15: ${ }^{1} \mathrm{H}$ Spectrum $\left(600 \mathrm{MHz}, \mathrm{CDCl}_{3}\right)$ of 8, Figure S16: ${ }^{13} \mathrm{C}$ Spectrum $\left(150 \mathrm{MHz}, \mathrm{CDCl}_{3}\right)$ of 8, Figure S17: ${ }^{1} \mathrm{H}$ Spectrum $\left(600 \mathrm{MHz}, \mathrm{CDCl}_{3}\right)$ of S-MTPA ester of 8 (12a), Figure S18: COSY Spectrum $\left(600 \mathrm{MHz}, \mathrm{CDCl}_{3}\right)$ of S-MTPA ester of 8 (12a), Figure S19: ${ }^{1} \mathrm{H}$ Spectrum $\left(600 \mathrm{MHz}, \mathrm{CDCl}_{3}\right)$ of $R$-MTPA ester of $\mathbf{8}(\mathbf{1 2 b})$, Figure S20: COSY Spectrum $\left(600 \mathrm{MHz}, \mathrm{CDCl}_{3}\right)$ of $R$-MTPA ester of 8 (12b), Figure S21: Antibacterial bioassay results for 7 against S. aureus and S. epidermidis, Figure S22: Phylogenetic analysis of Plocamium species based on COI data. 
Author Contributions: All the authors contributed to the conceptualisation of the manuscript; isolation and structural elucidation, J.B. and R.A.K.; biological evaluation, M.J.F. and M.L.G.; computational ECD analysis, Z.S. and M.A.H.; species identification, G.C.Z.; phylogenetic analysis and writing-original draft preparation, J.B., and writing-review and editing, R.A.K. All authors participated in proofreading the manuscript.

Funding: This research received no external funding. J.B. is thankful for the VUW Doctoral Scholarship.

Acknowledgments: Jan Vorster (VUW) is thanked for NMR and MS assistance. Shen Chong and the Robinson Research Institute are thanked for use of the ECD spectrometer. Joanne Harvey and the students of Chem 305 are thanked for preliminary data.

Conflicts of Interest: The authors declare no conflict of interest.

\section{References}

1. Lefranc, F.; Koutsaviti, A.; Ioannou, E.; Kornienko, A.; Roussis, V.; Kiss, R.; Newman, D. Algae metabolites: From in vitro growth inhibitory effects to promising anticancer activity. Nat. Prod. Rep. 2019. [CrossRef] [PubMed]

2. Dunlop, R.W.; Murphy, P.T.; Wells, R.J. A New Polyhalogenated Monoterpene from the Red Alga Plocamium angustum. Aust. J. Chem. 1979, 32, 2735-2739. [CrossRef]

3. Timmers, M.A.; Dias, D.A.; Urban, S. Application of HPLC-NMR in the Identification of Plocamenone and Isoplocamenone from the Marine Red Alga Plocamium angustum. Mar. Drugs 2012, 10, 2089-2102. [CrossRef] [PubMed]

4. Brownlee, R.T.C.; Hall, J.G.; Reiss, J.A. An application of the INEPT pulse sequence to the NMR assignment of halogenated marine natural products. Org. Magn. Reson. 1983, 21, 544-547. [CrossRef]

5. Cianciola, E.; Popolizio, T.; Schneider, C.; Lane, C. Using Molecular-Assisted Alpha Taxonomy to Better Understand Red Algal Biodiversity in Bermuda. Diversity 2010, 2, 946-958. [CrossRef]

6. Cremades, J.; Barreiro, R.; Maneiro, I.; Saunders, G.W. A new taxonomic interpretation of the type of Plocamium cartilagineum (Plocamiales, Florideophyceae) and its consequences. Eur. J. Phycol. 2011, 46, 125-142. [CrossRef]

7. Yano, T.; Kamiya, M.; Arai, S.; Kawai, H. Morphological homoplasy in Japanese Plocamium species (Plocamiales, Rhodophyta) inferred from the Rubisco spacer sequence and intracellular acidity. Phycologia 2004, 43, 383-393. [CrossRef]

8. Adams, N.M. Seaweeds of New Zealand; Canterbury University Press: Christchurch, New Zealand, 1994; p. 360.

9. Cooper, M.W. A Taxonomic Investigation into the Red Alga Plocamium within New Zealand. Master's Thesis, Victoria University of Wellington, Wellington, New Zealand, 2017.

10. Stierle, D.B.; Wing, R.M.; Sims, J.J. Marine natural products XI costatone and costatolide, new halogenated monoterpenes from the Red seaweed, Plocamium costatum. Tetrahedron Lett. 1976, 17, 4455-4458. [CrossRef]

11. Motti, C.A.; Thomas-Hall, P.; Hagiwara, K.A.; Simmons, C.J.; Willis, R.; Wright, A.D. Accelerated Identification of Halogenated Monoterpenes from Australian Specimens of the Red Algae Plocamium hamatum and Plocamium costatum. J. Nat. Prod. 2014, 77, 1193-1200. [CrossRef] [PubMed]

12. Woolner, V.H.; Jones, C.M.; Field, J.J.; Fadzilah, N.H.; Munkacsi, A.B.; Miller, J.H.; Keyzers, R.A.; Northcote, P.T. Polyhalogenated Indoles from the Red Alga Rhodophyllis membranacea: The First Isolation of Bromo-Chloro-Iodo Secondary Metabolites. J. Nat. Prod. 2016, 79, 463-469. [CrossRef]

13. Aliev, A.E.; Harris, K.D.M. $37 \mathrm{Cl} / 35 \mathrm{Cl}$ isotope effects in $13 \mathrm{C}$ NMR spectroscopy of chlorohydrocarbons. Magn. Reson. Chem. 1993, 31, 54-57. [CrossRef]

14. Bates, P.; Blunt, J.W.; Hartshorn, M.P.; Jones, A.J.; Munro, M.H.G.; Robinson, W.T.; Yorke, S.C. Halogenated Metabolites of the Red Alga Plocamium cruciferum. Aust. J. Chem. 1979, 32, 2545-2554. [CrossRef]

15. Blunt, J.W.; Bowman, N.J.; Munro, H.G.; Parsons, M.J.; Wright, G.J.; Yeow, K.K. Polyhalogenated Monoterpenes of the New Zealand Marine Red Alga Plocamium cartilagineum. Aust. J. Chem. 1985, 38, 519-525. [CrossRef]

16. Bruhn, T.; Schaumlöffel, A.; Hemberger, Y.; Bringmann, G. SpecDis: Quantifying the Comparison of Calculated and Experimental Electronic Circular Dichroism Spectra. Chirality 2013, 25, 243-249. [CrossRef] [PubMed] 
17. Pescitelli, G.; Bruhn, T. Good Computational Practice in the Assignment of Absolute Configurations by TDDFT Calculations of ECD Spectra. Chirality 2016, 28, 466-474. [CrossRef] [PubMed]

18. Polavarapu, P.L.; Covington, C.L. Comparison of Experimental and Calculated Chiroptical Spectra for Chiral Molecular Structure Determination. Chirality 2014, 26, 539-552. [CrossRef] [PubMed]

19. Dale, J.A.; Dull, D.L.; Mosher, H.S. Alpha-Methoxy-alpha.-trifluoromethylphenylacetic acid, a versatile reagent for the determination of enantiomeric composition of alcohols and amines. J. Org. Chem. 1969, 34, 2543-2549. [CrossRef]

20. Neises, B.; Steglich, W. Simple Method for the Esterification of Carboxylic Acids. Angew. Chem. 1978, 17, 522-524. [CrossRef]

21. Fulmer, G.R.; Miller, A.J.M.; Sherden, N.H.; Gottlieb, H.E.; Nudelman, A.; Stoltz, B.M.; Bercaw, J.E.; Goldberg, K.I. NMR Chemical Shifts of Trace Impurities: Common Laboratory Solvents, Organics, and Gases in Deuterated Solvents Relevant to the Organometallic Chemist. Organometallics 2010, 29, 2176-2179. [CrossRef]

22. Frisch, M.J.; Trucks, G.W.; Schlegel, H.B.; Scuseria, G.E.; Robb, M.A.; Cheeseman, J.R.; Scalmani, G.; Barone, V.; Mennucci, B.; Petersson, G.A.; et al. Gaussian 09 Revision D.01; Gaussian Inc.: Wallingford, CT, USA, 2010.

23. Adamo, C.; Barone, V. Toward reliable density functional methods without adjustable parameters: The PBE0 model. J. Chem. Phys. 1999, 110, 6158-6170. [CrossRef]

24. Perdew, J.P.; Burke, K.; Ernzerhof, M. Generalized Gradient Approximation Made Simple. Phys. Rev. Lett. 1996, 77, 3865-3868. [CrossRef]

25. Perdew, J.P.; Burke, K.; Ernzerhof, M. Generalized Gradient Approximation Made Simple. Phys. Rev. Lett. 1997, 78, 1396. [CrossRef]

26. Grimme, S. Semiempirical GGA-type density functional constructed with a long-range dispersion correction. J. Comput. Chem. 2006, 27, 1787-1799. [CrossRef]

27. Grimme, S.; Antony, J.; Ehrlich, S.; Krieg, H. A consistent and accurate ab initio parametrization of density functional dispersion correction (DFT-D) for the 94 elements H-Pu. J. Chem. Phys. 2010, 132, 154104. [CrossRef]

28. Grimme, S.; Ehrlich, S.; Goerigk, L. Effect of the damping function in dispersion corrected density functional theory. J. Comput. Chem. 2011, 32, 1456-1465. [CrossRef]

29. Weigend, F.; Ahlrichs, R. Balanced basis sets of split valence, triple zeta valence and quadruple zeta valence quality for $\mathrm{H}$ to Rn: Design and assessment of accuracy. Phys. Chem. Chem. Phys. 2005, 7, 3297-3305. [CrossRef]

30. Cammi, R.; Mennucci, B.; Tomasi, J. Fast Evaluation of Geometries and Properties of Excited Molecules in Solution: A Tamm-Dancoff Model with Application to 4-Dimethylaminobenzonitrile. J. Phys. Chem. A 2000, 104, 5631-5637. [CrossRef]

31. Cossi, M.; Barone, V. Solvent effect on vertical electronic transitions by the polarizable continuum model. J. Chem. Phys. 2000, 112, 2427-2435. [CrossRef]

32. Cossi, M.; Barone, V. Time-dependent density functional theory for molecules in liquid solutions. J. Chem. Phys. 2001, 115, 4708-4717. [CrossRef]

33. Cossi, M.; Rega, N.; Scalmani, G.; Barone, V. Polarizable dielectric model of solvation with inclusion of charge penetration effects. J. Chem. Phys. 2001, 114, 5691-5701. [CrossRef]

34. Cossi, M.; Scalmani, G.; Rega, N.; Barone, V. New developments in the polarizable continuum model for quantum mechanical and classical calculations on molecules in solution. J. Chem. Phys. 2002, 117, 43-54. [CrossRef]

35. Cossi, M.; Rega, N.; Scalmani, G.; Barone, V. Energies, structures, and electronic properties of molecules in solution with the C-PCM solvation model. J. Comput. Chem. 2003, 24, 669-681. [CrossRef]

36. Tomasi, J.; Mennucci, B.; Cammi, R. Quantum mechanical continuum solvation models. Chem. Rev. 2005, 105, 2999-3093. [CrossRef]

37. Marenich, A.V.; Cramer, C.J.; Truhlar, D.G. Universal Solvation Model Based on Solute Electron Density and on a Continuum Model of the Solvent Defined by the Bulk Dielectric Constant and Atomic Surface Tensions. J. Phys. Chem. B 2009, 113, 6378-6396. [CrossRef]

38. Legault, C.Y. CYLview, 1.0b; Université de Sherbrooke: Sherbrooke, QC, Canada, 2009. Available online: http://www.cylview.org (accessed on 9 April 2019). 
39. Stamatakis, A. RAxML version 8: A tool for phylogenetic analysis and post-analysis of large phylogenies. Bioinformatics 2014, 30, 1312-1313. [CrossRef]

40. Felsenstein, J. Confidence Limits on Phylogenies: An Approach Using the Bootstrap. Evolution 1985, 39, 783-791. [CrossRef]

(c)

(C) 2019 by the authors. Licensee MDPI, Basel, Switzerland. This article is an open access article distributed under the terms and conditions of the Creative Commons Attribution (CC BY) license (http://creativecommons.org/licenses/by/4.0/). 